Pamiętnik Literacki 2021, 1, s. 119-129

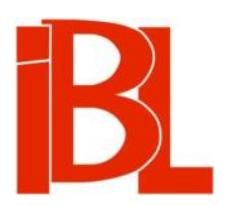

\title{
Dzieło - horyzont działań edytorskich
}

\author{
Wojciech Kruszewski
}




\section{DZIEŁO - HORYZONT DZIAŁAŃ EDYTORSKICH}

Gdy Paweł Bem opublikował w 2016 roku artykuł Dlaczego polskie edytorstwo naukowe nie istnieje ${ }^{1}$, rozważałem napisanie tekstu, który można by uznać za wyraz sprzeciwu wobec tego dobitnego i (do dzisiaj tak uważam) niesprawiedliwego w swej konkluzji głosu. Wówczas stwierdziłem jednak, że ani mój dorobek, ani temperament polemiczny nie upoważniają mnie do przyjęcia roli pierwszego obrońcy edytorstwa naukowego w Polsce. Niemniej prowadziłem z tym stanowiskiem swoje prywatne debaty, szukałem argumentów, kolekcjonowałem przykłady, a także próbowałem lepiej zrozumieć i racje, i cele Bema. Przez kolejne cztery lata nikt z moich koleżanek i kolegów nie odpowiedział na ten tekst wprost. Polskie edytorstwo naukowe (istniejące, a jakże, i to istniejące w postaci krytykowanej przez autora) zajęte było przygotowywaniem rozmaitych wydań, z mniej lub bardziej hermetycznymi rozważaniami, ale nie uzasadnianiem własnego istnienia. Tymczasem wraz z końcem roku 2020 pojawił się kolejny głos, który można potraktować jako wyraz poglądu zasadniczo zgodnego z przekonaniami Bema. Zmierzch edycji krytycznych? autorstwa Marii Prussak podejmuje bardziej szczegółową niż w przypadku pierwszego tekstu problematykę, lecz w swojej wymowie jest $z$ nim jednomyślny². Sądzę, że wystąpienie to nie może się spotkać z milczeniem.

Drugi ze wspomnianych artykułów ma w tytule znak zapytania, co odbieram nie jako świadectwo wątpliwości, bo autorka przedstawia swoje racje i poglądy w sposób jednoznaczny, ale jako zaproszenie do dyskusji o edytorstwie naukowym. Przyjmujacc to zaproszenie, bynajmniej nie zamierzam odpierać kolejnych zarzutów, rozliczać autorów $z$ terminologii (o której uporządkowanie słusznie upomina się Bem) czy drobiazgowo sprawdzać argumentów, które pod adresem tzw. tradycyjnego edytorstwa formułuja owi badacze. Raczej potraktuję ich tezy jako pretekst do powiedzenia czegoś, co uznaję za podstawę teoretyczną własnych prac edytorskich. A jest to podstawa zupełnie różna od tej zaproponowanej przez oboje autorów. Taki rodzaj prowadzenia sporu uważam za bardziej produktywny. Niekiedy będę musiał wyraźniej odnieść się do rzeczonych artykułów, ale nie celem dyskredytowania moich poprzedników. W nauce klarowne formułowanie własnych przekonań zawsze musi jednak do jakiegoś stopnia odbywać się w opozycji do innych poglądów.

Kluczowym punktem odniesienia dla Bema i Prussak jest orientacja metodolo-

1 P. B e m, Dlaczego polskie edytorstwo naukowe nie istnieje. „Teksty Drugie” 2016, nr 1.

2 M. Prus s a k, Zmierzch edycji krytycznych? „Pamiętnik Literacki” 2020, z. 4. 
giczna, którą określają oni jako „tradycyjne edytorstwo”, a którą uważają za niemożliwą obecnie do utrzymania, wręcz za szkodliwą dla studiów nad literaturą. Chodzi im o edytorstwo, w którym podejmuje się działania zmierzające do tego, by ustalić jeden, wolny od błędów, zgodny z intencją twórczą autora tekst dzieła literackiego. Innymi słowy, swój sprzeciw badacze ci wyrażają nie pod adresem każdego edytorstwa uprawianego w Polsce, lecz tylko pod adresem edytorstwa przyjmującego za podstawę dokumenty literackie i zmierzającego do opracowania kanonicznej wersji tekstu. Zarzuty Bema i Prussak opierają się na dwojakich argumentach - wynikajacych $\mathrm{z}$ aktualnego stanu edytorstwa i teoretyzujacych refleksji edytorskich oraz ze szczegółowej wiedzy na temat historii konkretnych problemów wydawniczych. Mimo różnic oba stanowiska mają ważny punkt wspólny, wprawdzie nieujawniany wprost, ale dajacy się łatwo rozpoznać. Zidentyfikujemy go, gdy przyjrzymy się zarówno krytykowanym przez Bema i Prussak rozstrzygnięciom, jak i aprobowanym przez nich rozwiązaniom wydawniczym. Tym wspólnym mianownikiem jest kryzys pojęcia dzieła literackiego, którego miejsce zajmuje pojęcie dokumentu literackiego. Moim zdaniem, to stąd właśnie bierze się intensywna krytyka tezy o możliwości uchwycenia tekstowej tożsamości dzieła literackiego.

Utwór literacki pozostaje w nieoczywistej łączności z tekstem, ze „swoim” tekstem³ (Chciałbym to „swoim” napisać bez cudzysłowu, ale na razie chyba lepiej tak to zostawić.) Paradoksalność tego związku widać, gdy dokładnie przyjrzymy się aktowi lektury. Dzieło literackie możemy poznać wyłącznie dzięki tekstowi. Nie ma znaczenia rodzaj nośnika; odczytane czy odsłuchane - wszyscy poznajemy to samo dzieło tak długo, jak długo odczytywana bądź odsłuchiwana jest ta sama sekwencja znaków językowych. Poznajemy to samo, ale poznajemy inaczej. W idealnej sytuacji nieuchronne odrębności w poznawaniu dzieła pojawiają się dopiero na kanwie lektury, wynikają z różnych konkretyzacji i odmiennego rozumienia, spowodowane są różną wrażliwością, różnym wykształceniem czy doświadczeniem czytelników. Nierzadko zachodzą jednak sytuacje, gdy w dziele, konstytuującym się w odbiorze na podglebiu tekstu, coś jest nie tak. Czytamy tekst, obcujemy w swoim umyśle $z$ dziełem, ale wracamy ze sfery dzieła do tekstu, bo coś wzbudza nasz niepokój. Powracamy do tekstu, by zweryfikować to coś, potwierdzić lub zmodyfikować. Tak jest np. wtedy, gdy nasza lektura potyka się o omyłkę.

Wybrałem ten właśnie problem do zaprezentowania mojego stanowiska, ponieważ został on wspomniany przez Prussak. I jest to chyba jedno $z$ ważniejszych, bo symptomatycznych miejsc w jej wywodzie:

Pojęcie błędu - z wyjątkiem oczywistych literówek - jak od początku podkreślali to świadomi tekstolodzy, jest subiektywne, bo podporządkowane indywidualnemu odczuciu i językowej kompetencji osoby oceniającej tekst pod tym kątem ${ }^{4}$.

3 Wiele lat temu zaczałem na własne potrzeby naukowe adaptować określone propozycje $z$ zakresu teorii dzieł literackich. Istotną inspiracją dla tych przemyśleń była praca T. Ku la s a Edytorstwo dzieł literackich $w$ świetle filozofii Romana Ingardena („Roczniki Humanistyczne” 2003, z. 1). Uważny czytelnik bez trudu znajdzie w moim artykule odniesienia do koncepcji Ingardena, nie będę ich więc opatrywał rodowodem.

4 Prussak, op. cit., s. 34. 
Podany przez autorke przykład takiej sytuacji pozwolę sobie jednak zastapić przykładem mi bliższym, a chyba też bliższym nam wszystkim, bo nie tak odległym czasowo. Oto późny wiersz Anny Kamieńskiej zatytułowany Plan miasta:

To miasto jest planem miłości
na tej ulicy mnie spotkałaś
tu śnieg połączył nasze usta
tu się żegnaliśmy
i patrzyłeś za mną długo
tu pobrały się nasze drogi
tu zamieszkały nasze dłonie
tu biegłam do ciebie w chorobie
tu wiozłam cię raz ostatni
tu się ukryłeś przede mną
tu nie przestaję cię szukać5

Czy w drugim wersie mamy do czynienia z literówką? Czy zamiast „spotkałaś” nie powinno być „spotkałeś”? Rzecz ta ma pierwszorzędne znaczenie dla zrozumienia utworu. Ponieważ nie udało mi się odnaleźć żadnego autorskiego przekazu tego tekstu, a jedynym dostępnym jest pośmiertny druk książkowy z formą „spotkałaś”, przy rozstrzyganiu tej kwestii pozostaje intelektualna gra z możliwymi wariantami, a ostatecznie lektura subiektywna, tj. podporzadkowana indywidualnemu odczuciu odbiorcy. Dla mojego wywodu nie jest aż tak istotne, żeby sformułować tutaj w tej sprawie jakąkolwiek konkluzję ${ }^{6}$ W konkretnej edycji, jeśli tylko ma to być edycja tradycyjna w rozumieniu Prussak i Bema, decyzję trzeba byłoby jednak podjąc: albo zmienić na „spotkałeś”, albo zostawić „spotkałaś”. Dla mnie ważne jest teraz samo dostrzeżenie specyficznego ruchu. Tekst jest punktem wyjścia w poznawaniu wiersza. W wierszu odnajdujemy miejsce, które stawia nam opór w rozumieniu. A od rozumienia zależy sposób, w jaki wydamy wiersz. Próbujemy ów opór złamać, dopuszczając domysł, że mamy w tekście do czynienia z omyłką literową. I decydujemy, czy wraz ze zmianą litery ów opór znika, a rozumienie nas satysfakcjonuje. Możemy jednak przekuć opór w nieoczywiste zrozumienie utworu, a formę „spotkałaś” zakonserwować w tekście. Bez względu na decyzję i jej zmaterializowany w tekście efekt nieuchronnym etapem w procesie poznawania utworu jest ruch wstecz. Najpierw był to ruch od tekstu do dzieła, od materialnej tekstowej konkretności ku intencjonalnie bytującemu, wykraczającemu poza tekst dziełu. Później od tego idealnego dzieła znów w stronę tekstu, by się upewnić: istotnie „spotkałaś”? Jeśli zdecydujemy się na meliorację tekstu, uczynimy to ze względu na domniemany porządek dzieła. Jeśli zaniechamy poprawki, to również ze względu na domysł że dzieło tego nie potrzebuje. To ów idealny kształt dzieła wymaga od nas (lub nie wymaga) korekty w tekście. Czynnikiem tym nie jest rozbisurmaniona wola edytora. Zwróćmy uwagę, że raczej trudno przyznać omówionej zmianie taką samą zasadność jak domysłowi, iż w Planie miasta czwarty wers („tu się żegnaliśmy”) powinien zostać

5 A. Kamieńska, Plan miasta. W: Poezje zebrane. Red. W. Kruszewski. T. 3. Lublin 2020, s. 384 .

6 Wskazanemu w tym wierszu problemowi poświęciłem artykuł napisany wraz z grupa studentów i doktorantów: Edyt or stw o KU L, „Plan miasta” - późny erotyk Anny Kamieńskiej i jego (nad)interpretacja („eleWator” 2020, nr 2). 
zastąpiony przez: „tu się pożegnaliśmy”. Wygląda na to, że owe dwa porządki, tekstowy i związany z dziełem, warunkują się wzajemnie. Ich uzgodnienie jest w podobnych sytuacjach probierzem jakości prac edytorskich. To w ten sposób ostatecznie weryfikujemy, czy koniektura jest właściwa i czy tekst ustalony przez edytora został ustalony poprawnie. W gruncie rzeczy tak właśnie postępowała Zofia Stefanowska, przywołana w artykule Prussak, wskazujac przykład edytorskiego błędu we fragmencie o liściu czy liściach na czole jednej $z$ Mickiewiczowskich postaci ${ }^{7}$.

Przedstawiony tutaj w uproszczeniu ruch towarzyszacy lekturze - ruch bardzo często doświadczany w pracy edytorskiej - pozwala potwierdzić wątpliwości Prussak i ujrzeć ten zasadniczy problem we właściwym świetle, ale też w całym skomplikowaniu: nawet identyfikacja oczywistej literówki może nie być oczywista. Chciałbym jednak podkreślić, że zaniechanie działania i rezygnacja $z$ jakiegokolwiek komentarza wcale nie unieważni tego kłopotu. Przed subiektywnością w pracy z utworami literackimi po prostu nie ma ucieczki ${ }^{8}$. Najbardziej podstawowe, wydawałoby się, czynności edytorskie zawsze są uwikłane w konkretyzację i w interpretację, a więc w to, jak postrzegamy świat dzieła, nie tekstu. A dzieje się tak dlatego, że choć takie działania materializują się w tekście dzieła, podejmowane są ze względu na coś, co się do tego tekstu nie sprowadza. $Z$ drugiej strony, to coś nie jest skazane na pastwę swobodnych skojarzeń. Owa subiektywność jest wyraźnie powściągana przez obiektywność zapisu utrwalonego w konkretnym dokumencie.

Wielość ujęć właściwej postaci tekstowej dzieła nie oznacza więc ich zupełnej dowolności. Weryfikuja je: dokumentacja literacka, znajomość języka autora, jego zwyczajów pisarskich, praktyk wydawniczych określonego miejsca i czasu, kontekst historyczny... Mnogość detali, które trzeba przyswoić, i kontekstów, które trzeba uruchomić, aby uprawdopodobnić decyzję edytorska czy jej zaniechanie, $z$ trudem daje się wpisać w jeden algorytm postępowania. Ale czy w związku z istnieniem owego horyzontu subiektywności postulowane przez Bema i Prussak edytorstwo dojrzałe, wyrosłe $z$ etapu naiwności dzięki przyswojeniu zachodnich prac teoretycznych, zawstydzone swoimi dotychczasowymi potknięciami, winno odrzucić ideał tekstu ustalonego krytycznie? Moim zdaniem - nie.

Jak rozstrzygnać, czy dany domysł jest uzasadniony, czy rzeczywiście mamy do czynienia $z$ omyłka, a zaproponowana przez nas lekcja (to kolejny, równie nieoczywisty krok) jest poprawna, zgodna $z$ wolą twórczą autora? Uzyskujemy tę możliwość dzięki właściwie skonstruowanej nocie edytorskiej i dzięki towarzyszącej decyzjom wydawniczym dokumentacji przedstawionej w rejestrze odmian. Czytelnicy otrzymują całą edycję, nie tylko część zawierającą tekst dzieła. Wszystkie zebrane w niej informacje sa po to, żeby czytelnik niczego nie musiał brać na wiarę, żeby mógł sprawdzić choćby owe miejsca zawieszone wyłącznie na subiektywnych przeświadczeniach edytora. Edycja krytyczna jako całość jest, a przynajmniej winna być, nie tylko naczyniem dostarczającym tekst dzieła, lecz i narzędziem pozwa-

$7 \quad$ Pruss ak, op. cit., s. 36, przypis 24.

8 Termin „subiektywność” rozumiem tak, jak zaproponował to S. J u d y c ki w Epistemologii (t. 1. Poznań-Warszawa 2020, s. 179-183). W moim najgłębszym przekonaniu sądy dotyczące dzieł literackich mogą być wyłącznie subiektywne epistemologicznie. Nie oznacza to jednak (o czym dalej), że są niesprawdzalne. 
lającym zweryfikować poprawność skonstruowania tego tekstu. Rejestr odmian nie służy więc temu, żebyśmy mogli zrekonstruować na jego podstawie dokument. Oryginalnego dokumentu (co słusznie zauważa Prussak) nie zastapi nic, więc jeśli kogoś on interesuje - zaprośmy taką osobę do archiwum albo dajmy jej możliwie najwierniejszą kopię dokumentu.

Sądzę, że za podejściem podkreślającym niemożność przekroczenia porządku dokumentalnego skrywa się nieporozumienie. Cele edytorstwa naukowego m o ga być realizowane w procesie krytycznego ustalania tekstu dzieła. Nie m u s za! Bem zupełnie słusznie upomina się o inny model uprawiania dyscypliny. Ale nie mogę się zgodzić na wykluczenie możliwości uprawiania tradycyjnego edytorstwa. Ponieważ jednak dzieło bytuje intencjonalnie, nieuchronnie oznacza to poznawczy subiektywizm. Skoro zaś od subiektywizmu nie ma ucieczki, niech to będzie chociaż subiektywizm sprawdzalny, a ostatecznie: falsyfikowalny. W przypadku właściwie skonstruowanej edycji krytycznej jest to możliwe, a ewentualny brak weryfikacji obciąża wówczas odbiorcę, nie edytora. Jeśli zaś takiej części w edycji nie ma, oznacza to, że edycja została źle przygotowana. Ale nie należy $\mathrm{z}$ tego wyciagać wniosku, że edycja krytyczna tekstu dzieła literackiego, edycja, dla której kluczowa jest koncepcja kanonu tekstowego, jest w ogóle niemożliwa.

Konkludując ten etap prezentacji moich sądów o edytorstwie naukowym, zapytam: czym wobec tego jest ów Święty Graal edytorstwa naukowego, kanon tekstowy? Jeśli intencja autorska, błąd i omyłka, emendacja i koniektura - kategorie niezbędne do zrealizowania tak pomyślanego projektu naukowego - są mocno zależne od indywidualnego osądu, trzeba stwierdzić, że tekst dzieła będzie miał zawsze status hipotetyczny. To jednak nie znaczy, że edytorstwo, które taką hipotezę stawia w centrum swoich dociekań, traci status naukowy. Paradoksalnie, jest dokładnie na odwrót. To właśnie tekst dzieła jako hipoteza badawcza, a nie jako wierne odwzorowanie zapisu $z$ dokumentu, jest gwarantem naukowego charakteru naszej dyscypliny. Tak rozumianej hipotezie badawczej służą wszystkie czynności angażujące kompetencje pismoznawcze, bibliograficzne, biograficzne, językoznawcze, literaturoznawcze, tekstologiczne, historyczne... a choćby i botaniczne.

W pracy nad tekstem ustalonym krytycznie wydawca musi sobie uświadamiać, jakie sa granice dzieła. Edytorzy formułuja odpowiedź na pytanie o te granice w sposób praktyczny: przygotowując tekst. Z części sygnałów tekstowych pochodzących $z$ podstawy druku rezygnują, inne sygnały konserwują. Konsekwencje dla dzieła, z jakimi wiążą się te czynności, widać choćby wtedy, gdy przyjrzymy się procedurom, dla których hasłem wywoławczym jest modernizacja. Przetransliterowanie zapisu $z$ dokumentu, zachowanie wszystkich znaków z podstawy najczęściej nie wystarcza, aby dzieło mogło być poznawane właściwie. Kilkakrotnie przeprowadziłem ze studentami proste prace ćwiczeniowe pozwalające zauważyć, że fragment, w którym ja widzę jedynie świadectwo oddziaływania dawnej normy interpunkcyjnej czy ortograficznej, słabo przygotowani czytelnicy traktują jako miejsce znaczące, nawet bardzo znaczące. I że rozkwita wtedy tysiąc nadinterpretacji wynikających $z$ ignorancji, nie zaś ze znajomości realiów epoki, w której powstał dany dokument. $Z$ roku na rok coraz częstsze są też sytuacje - ma to związek $\mathrm{Z}$ coraz płytszym zakorzenieniem młodszego pokolenia w kulturze druku i właściwych dla niego konwencjach - że np. dłuższy wers poetycki, który nie mieści się w jednym 
rządku pisma, wobec czego złamany został w dwa rządki, traktowany jest jak dwa wersy. Im dana konwencja graficzna odleglejsza od naszych czasów, tym większe pole do nieporozumień. A rolą wydawcy naukowego przygotowującego edycję krytyczną nie jest konserwowanie osobliwości techniki drukarskiej czy redakcyjnej, ale tylko (i aż) tego, co ma związek z porządkiem dzieła.

I tu nawet wzmocniłbym sformułowane przez Prussak uwagi dotyczace modernizacji. Moim zdaniem, warstwa brzmieniowa stanowi integralny element dzieła literackiego bez względu na to, czy chodzi o poezję, czy o prozę, i niezależnie od tego, czy dana forma jest poprawna $z$ punktu widzenia historii języka i na tle dzisiejszej normy. Warstwa ta jest zorganizowana właściwie (pomijam ewidentne omyłki, o których wspomniałem wcześniej), jeśli jest autoryzowana, a więc jeśli można ustalić, że dany zapis został bezpośrednio lub pośrednio zatwierdzony przez autora. Cechę tę w znakomitej większości sytuacji można dość dobrze określić na podstawie świadectw zewnętrznych wobec danego dokumentu i na podstawie studiów wewnętrznych. Choćby dlatego zmiana Norwidowskich form „koketeria” i „mystyka” na „kokieteria” i „mistyka” nie może być we współczesnej edycji uznana nawet za modernizację, ale za deformację, powodowana źle rozumianą troską o dobro autora Assunty. Dlatego np. przygotowując edycje krytyczną wiersza [Nad woda wielka $i$ czysta], powinniśmy zostawić formy z akaniem: „Ta woda widzę dokoła”, wbrew Stanisławowi Pigoniowi i Czesławowi Zgorzelskiemu, którzy optowali za zmienieniem zapisu i za wersją: „Tę wodę widzę dokoła”9 . Używam określenia „zmienianie”, nie „poprawianie”, bo w oryginalnych, przywołanych tu zapisach nic nie jest złe. Jest odmienne. To tylko nasz zmysł językowy, szlifowany przez ogólnopolskie, wszechobecne media i przez system edukacji skrojony wedle jednego wzorca, każe nam to dostosować do powszechnie akceptowalnej dziś formy.

Podobnie $\mathrm{w}$ dziedzinie przestankowania. $\mathrm{W}$ wielu znanych mi dziełach $\mathrm{z}$ wieku XIX znaki przestankowe wprowadzone są niezgodnie $\mathrm{z}$ obowiązującymi dziś regułami, ale pilnowanie się ich podczas lektury pozwala przeczytać utwór tak, jak autorzy chcieli, żeby on wybrzmiewał. I nie trzeba tu przywoływać wielkiej sztuki poetyckiej i kłopotów wydawniczych choćby z Norwidowską interpunkcją. Nawet w publicystycznych Rachunkach Józefa Ignacego Kraszewskiego pełno jest znaków, które na pierwszy rzut oka są dla nas niezrozumiałe: cztero- i pięciokropki, podwójne pytajniki i podwójne wykrzykniki, myślnik poprzedzony średnikiem... W normalizowaniu takich miejsc przez wydawce jest coś nie tyle $z$ pychy, nie tyle nawet $\mathrm{z}$ ignorancji, ile $\mathrm{z}$ mylnego rozpoznania interesu czytelnika. Zastępowanie takich (przyznajmy to uczciwie) kłopotliwych dziś dla odbiorców miejsc formami mieszczącymi się w nudnym nowoczesnym horyzoncie oczekiwań wypacza dzieło w całym bogactwie jego brzmieniowego i retorycznego zorganizowania. Z Mickiewicza nie róbmy Jacka Dehnela, a z Kraszewskiego - Krzysztofa Ibisza! Ułuda jest przekonanie, że owe zbędne działania na języku przybliżą naszych klasyków współczesnemu pokoleniu ${ }^{10}$.

9 S. Pi go ń: Dwie właściwości gwarowe w języku Mickiewicza. „Język Polski” 1949, nr 5; Jeszcze o akaniu Mickiewicza. Jw., 1960, nr 4. - A. M i c ki e w i c z, Wiersze 1829-1855. Oprac. Cz. Zg orzels ki. Wrocław 1981, s. 327. Dzieła wszystkie. T. 1, cz. 1.

10 Na marginesie... Nie tak dawno usłyszałem od polonisty o imponującym dorobku i uznanej w po- 
Brzmi to trochę jak manifest, więc pozwolę sobie wrócić do wyłożonej już tezy o tekście kanonicznym jako hipotezie badawczej. Właściwe rozumienie dzieła literackiego pozwala wyznaczyć granice ingerencjom edytorskim. Jeśli uznamy błędnie, że dzieło literackie to po prostu określone kwantum informacji semantycznej, nic nie powstrzyma deformacji polszczyzny, w jakiej te dzieła zostały uformowane. Jeśli błędnie odróżnimy to, co pod względem językowym czysto konwencjonalne, od tego, co obciążone funkcją dziełotwórczą, ryzykujemy, że pozbawimy dzieło jego istotnego wymiaru, bez którego przestaje ono być tym właśnie dziełem, o którego poznanie zabiegamy. Podałem przykłady natury fonetycznej i interpunkcyjnej, ale rzecz dotyczy też np. graficznej organizacji utworów poetyckich. Trudno dziś kwestionować, że dzieła poetyckie to w jakiejś mierze także utwory graficzne, obliczone na to, że w druku będą się w specyficzny sposób prezentować naszemu wzrokowi ${ }^{11}$. Tej warstwie również należy się odpowiednia pieczołowitość. A w związku z tym ani systemowe zaniechania, ani niczym nieograniczona inwencja nie sa dobrymi wyjściami. Dzieło literackie należy przedstawić graficznie tak, aby oddać jego istotny rys w tym zakresie.

Przygotowany przez edytora krytycznie tekst dzieła nigdy nie powinien być traktowany jako ustalony ostatecznie i bezspornie. Bo co, jeśli po latach się okazuje, że ustalony przez wydawce tekst jest trudny do utrzymania? Choćby tekst Pana Tadeusza (przykład podany przez Prussak), w którym między „zająca” a „charty” zamiast „psów” edytor wstawił „pył”. Co wtedy? Przyjmujemy wówczas inną hipotezę, taką, w której tego „pyłu” nie ma. Taką, która lepiej służy uniwersum dzieła. I ma ona swój walor tak długo, jak długo ktoś przekonująco nie uzasadni innej postaci tekstowej Mickiewiczowskiego arcypoematu. W tego rodzaju przypadkach sfalsyfikowana hipoteza trafia po prostu na karty historii naszej dyscypliny. I tyle. Tak właśnie działa nauka. Ale nie należy z takich sytuacji wyciagać wniosku, że tekst ustalony krytycznie jest ideałem utopijnym. Historia edycji klasycznych utworów w literaturze polskiej dowodzi, że można zrekonstruować porządek dający się opisać jako linia doskonalenia naszego rozumienia tekstu dzieła, a nie jako chaotyczne majaczenie szalonych umysłów. Zestawmy choćby kolejne edytorsko ważne publikacje Vade-mecum Cypriana Norwida. Czy naprawdę jedyne, co z tego zestawienia wynika, to wzbudzająca konfuzję feeria fantazji edytorskich? Czy nie widać tu przede wszystkim stopniowego narastania świadomości edytorskiej, formułowania i falsyfikowania kolejnych propozycji badawczych, a w efekcie - stopniowego pomnażania wiedzy pewnej o tekstowej tożsamości cyklu? I piszę o wiedzy wykrystalizowanej w edycjach tego zbioru, nie o artykułach na jego temat.

Ale rzeczywiście, nierzadko mamy do czynienia $z$ trudną do uzasadnienia od-

lonistyce pozycji, autora licznych prac wydawniczych, że modernizacja musi być zgodna $z$ istniejącym aktem o charakterze prawnym, z polską normą dekretującą zakres modernizacji tekstów dawnych. Nic bardziej błędnego. W modernizacjach materializuje się fragment tezy badawczej. Ta zaś nie zależy od prawodawcy, choćby działającego w najlepszej wierze. Modernizacja nie jest czynnością, która bez szkody dla dzieła może być wykonywana przez maszynę czy przez przeszkolonego dyletanta. Stawką jest tu nie uniknięcie wyroku skazującego, ale prawda o dziele, o autorze, o epoce.

11 Zob. np. W. S a d ow s ki, Wiersz wolny jako tekst graficzny. Kraków 2004. 
miennościa. Taki jest koszt pracy naukowej nad dziełem literackim. Ujmę to inaczej, odwołując się do słów, które kiedyś usłyszałem od Józefa Ferta. Powtarzam je, bo uznaję ich słuszność: każde pokolenie musi wydać klasyków po swojemu. Dlaczego Zgorzelski usuwał Mickiewiczowskie akanie? Dlaczego ja dziś skłonny byłbym je zostawić? Nie jest tak, żeby kluczowa była kwestia pojawienia się jakichś nowych dowodów w sprawie języka Adama Mickiewicza. Dokumentacja w tej sprawie nie zmieniła się. Jeśli różnię się w tej kwestii od Zgorzelskiego, to przede wszystkim dlatego, że inaczej identyfikuje granice dzieła literackiego i odmiennie widzę rolę dokumentacji literackiej w procesie edytorskim ${ }^{12}$. Język nie znajduje się na zewnątrz utworu, ale stanowi jego istotny element. Przekonanie to jest dla mnie ważniejsze niż to, że kiedyś przy podobnej okazji Mickiewicz najprawdopodobniej zdecydował o językowym znormalizowaniu zapisu.

Hipoteza, którą jest tekst dzieła, nieuchronnie wikła się więc w założenia teoretycznoliterackie. Te zaś się zmieniają. Ale też nie ma hipotez bezzałożeniowych. Specyfika humanistyki polega na tym, że nie istnieją metody weryfikacji hipotez takie jak w matematyce. Uniemożliwia to sama natura naszej dyscypliny, która dla swoich prac potrzebuje nie tylko dokumentów, lecz także - a nawet przede wszystkim - dzieł, podobnie jak matematyka potrzebuje aksjomatów. Niemożliwe są u nas dowody, możliwa jest jednak argumentacja, prezentowanie racji. I ich weryfikowanie.

$Z$ tej perspektywy, moim zdaniem, dałoby się odmiennie spojrzeć na problem wielowariantowości dzieł literackich, zjawiska poświadczonego dokumentami pozostałymi z procesu twórczego. Dzieła literackie mają swoje bruliony, mają kolejne redakcje, reedycje $z$ odmienionymi tekstami tych dzieł. Bem i Prussak najzupełniej słusznie upominaja się o ich uwzględnienie w pracach wydawniczych. Sam jednak fakt, że w jakiejś wersji tekstu autor nie wziął pod uwage tych czy innych istniejących wcześniej fragmentów (świetny przykład podaje Prussak - w didaskaliach do trzeciej części Dziadów Mickiewicz raz każe wejść na scenę więźniom w szlafrokach, a drugi raz nic o szlafrokach nie wspomina), nie przekreśla możliwości ustanowienia przez wydawcę tekstu Dziadów drezdeńskich. Wskazując jedną z redakcji jako podstawę prac nad ustaleniem tekstu dzieła, edytor formułuje część hipotezy badawczej. Prawda jest, jak zauważa Prussak, że - tu upraszczam - w takich sytuacjach obie wersje sa autoryzowane. Śmierć autora nie czyni z nich wersji nieautoryzowanych. Ale prawdą też jest, że owe autoryzowane wersje można ułożyć chronologicznie. Autoryzacja jest czasowa, obowiązuje od momentu pojawienia się danej wersji do momentu pojawienia się wersji kolejnej, która odbiera w aktualnym czasie autoryzację wersji wcześniejszej. A autoryzacja ostatniej wersji kończy się wraz ze śmiercią autora. Jeśli zaprzeczyć, że pojęcie autoryzacji umożliwia zobaczenie w kolekcji dokumentów systemu wzajemnie unieważniających się wersji, jak

Dziękuję Pani U rszuli J án czy k za zwrócenie mi uwagi na przechowywany w Bibliotece Uniwersyteckiej KUL maszynopis o sygn. Rkps 2506: Fert Józef, ed. Vade-mecum Norwida. Jest to pochodzaca z roku 1987 recenzja wydawnicza Cz. Zgor zels ki e go. Widać w niej wyraźnie, że Zgorzelski wielką wagę przykładał do działań modernizacyjnych, lecz modernizowane cechy językowe uznawał za miejsca pozwalające uzupełnić wiedzę o autorze, nie za integralną, nienaruszalną warstwę dzieła literackiego (zob. s. 5 recenzji, $52 \mathrm{w}$ teczce). 
w ogóle wyjaśnić, że autor zdecydował się taką kolejną wersję powołać do istnienia? $Z$ tego wyciągam wniosek, że gdy nie zachodzą żadne nadzwyczajne okoliczności (jak to, że autor wyraził wprost wolę, by którąś $z$ wersji wcześniejszych uczynić podstawa prac wydawniczych, albo że wersja ostatnia jest niewątpliwie nieukończona), to właśnie ostatnia (nie ostateczna!) wersja ma dla wydawców naukowych szczególną moc zobowiązująca. Jeśli tylko można ją uznać za ukończona, to właśnie ona ma większe szanse, by stać się podstawą wydania. Bo autor wyraził swoją wolę, bo zmienił - niekoniecznie poprawił. I dlatego, że po tej wersji nie ma już kolejnej autoryzowanej.

Prawdą jest także, że autoryzacja autoryzacji nierówna. Inaczej to wygląda w sytuacji, gdy autor ma absolutną swobodę w decydowaniu o swoim tekście, a inaczej, gdy jest poddany przeróżnym presjom, np. ze strony urzędu cenzorskiego, choć autorzy miewają też zwyczaj samodzielnego, uprzedzającego cenzurowania się. Ale i chronologia, i stopień autoryzacji (sam posługuję się pojęciami autoryzacji czynnej i biernej) winny być uznawane za wskazówkę przy określaniu właściwej podstawy tekstowej, nie za skuteczną, trwała blokadę przeprowadzenia pracy edytorskiej. Trzeba w tym materiale, niejednokrotnie bardzo splątanym, trudnym, szukać jakiejś racjonalności. I przekuwać to w konkretne decyzje wydawnicze.

Bardzo rzadkie sa zjawiska, gdy jednego tekstu dzieła literackiego nie sposób określić. Jako dobry przykład podałbym pewne dzieła Tadeusza Różewicza, poety, który grał wariantywnością na oczach czytelników, komponując niektóre swoje publikacje tak, żeby uwidocznić proces tworzenia, niekiedy nawet proces zapisywania. W tym przypadku dzieło po prostu nie ma jednego tekstu, lecz konstytuowane jest przez wiele równoprawnych tekstów. Ale jednak: przez wiele, a nie przez wszystkie! Różewicz nie podał wszystkich istniejących odmian tekstu do książki Historia pięciu wierszy ${ }^{13}$. Być może podał tylko niektóre. Odnalezienie w jego archiwum innych wersji każdego $z$ pięciu utworów $z$ tej publikacji, wersji nam dziś nieznanych, nie umożliwia nam wydania innej Historii; musimy się ograniczyć do tego, co zdecydował się ujawnić sam autor (lub co mógł ujawnić). Jest to sytuacja zupełnie wyjątkowa, ale również tutaj, chciałbym to mocno podkreślić, zaproponowane rozwiązanie przyjąłbym ze względu na rozpoznany przeze mnie charakter dzieła.

Edytorstwo naukowe, w którego centrum znajduje się idea edycji krytycznej z jednym tekstem kanonicznym dzieła, ma, moim zdaniem, swoje wyraźne ograniczenie. Jawi mi się ono, gdy próbuję domyśleć do końca kategorie dzieła i autoryzacji. W archiwach literackich znajduje się wiele dokumentów, o których trudno powiedzieć, że zawierają zapisy dzieł. Najczęściej nie można nawet stwierdzić, czy są to fragmenty większych całości, czy też zarzucone projekty literackie, które miały skończyć się tekstem dzieła. Doskonałe przykłady takich dokumentów można wskazać w archiwum Mickiewicza. Wiersz [Gęby za lud krzyczace] znajduje się $\mathrm{w}$ dokumencie $\mathrm{w}$ jednym $\mathrm{z}$ muzeów paryskich ${ }^{14}$. Zapis ten został uczyniony wierszem

13 Pierwsza edycja: Kłodzko 1993.

14 Owej sprawie poświęciłem krótki artykuł Mickiewiczowski rękopis „№ 38” raz jeszcze („Sztuka Edycji” 2018, nr 1). 
nie przez Mickiewicza, lecz przez tradycję edytorska. Istnieją powody, żeby potraktować go jako wariant części innego zapisu poetyckiego, nie za autonomiczny utwór. Tylko w takich sytuacjach uznałbym tezę o niemożności ustalenia tekstu kanonicznego, a także o konieczności zastąpienia edycji krytycznej edycją dokumentacyjną. Jakkolwiek by to było trudne, tak właśnie trzeba zrobić; ale to ze względu na charakter dokumentacji literackiej, nie ze względu na postulaty jakiegokolwiek badacza co do materialności tekstu.

Na koniec muszę sformułować jedną wątpliwość. Dotyczy ona wyrażonej przez oboje autorów wiary, że edycja cyfrowa otwiera przed edytorami zupełnie nowe obszary, dotąd im nieznane. Bem pisze wprost, że nie chodzi tu wyłącznie o dostarczenie narzędzi będących $\mathrm{w}$ stanie unieść obszerną dokumentację, której nie udźwignie edycja papierowa; chodzi o stworzenie czegoś zupełnie nowego, odmiennego typu edycji. Ja w to na razie nie wierzę.

Przede wszystkim nie wierzę w to dlatego, że możliwe są edycje, o które upominają się Prussak i Bem, ale realizowane tradycyjnymi środkami redakcyjnymi i poligraficznymi. Weźmy chociażby Alchemię rękopisu Marka Troszyńskiego ${ }^{15}$. Autor obył się tam $z$ powodzeniem bez porządku związanego $z$ dziełem, a jego opracowanie rękopisów Juliusza Słowackiego ma wszelkie znamiona ważnej i rzetelnej edycji dokumentacyjnej, przygotowanej z pełną świadomością zmian, które zaszły na świecie w opracowaniu tego typu materiałów. Innymi słowy, nie sądzę, żeby w najistotniejszych sprawach edycja materiału dokumentalnego związanego z Samuelem Zborowskim przygotowana narzędziami cyfrowymi różniła się znacząco od tej książki. Bo np. udostępnienie użytkownikom takiej edycji cyfrowej (nie czytelnikom! - to ważne) narzędzia do manipulowania zdjęciami, choćby zmiany kontrastu obrazu, to dla mnie nie powód, aby taką edycję cyfrową oceniać lepiej niż Alchemię rękopisu, żeby uznać to za ową przewidywaną nowość.

Nie wierzę w przełomowość edycji cyfrowych także dlatego, że jak dotąd wyraźnie adaptują one narzędzia wypracowane przez edytorstwo tradycyjne. Bem wspomina o standardzie Text Encoding Initiative (TEI) w kodowaniu edycji cyfrowej. Jest to - tak wynika też z moich obserwacji - bardzo popularne, często używane rozwiązanie do zakodowania edycji w języku XML. Ale znakomita większość proponowanych w tym standardzie znaczników odpowiada po prostu kategoriom wziętym $z$ tradycyjnego edytorstwa. TEI-owska ontologia jest $w$ gruncie rzeczy bardzo tradycyjna. TEI nie wyklucza stworzenia edycji cyfrowej, w której podamy jeden, ustalony, wolny od błędów, zgodny $z$ domniemaną intencją twórczą autora

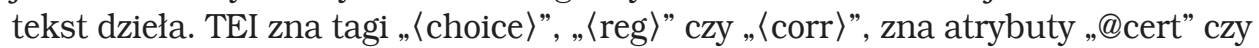
„@evidence”, dzięki którym możliwe są nie tylko transliteracje i transkrypcje, ale i modernizacje, emendacje, koniektury... ${ }^{16}$ Natomiast bez wątpienia TEI umożliwia obnażenie wszystkich działań edytorskich, które do tej pory były ukrywane w edycji. W kodzie XML takie uniki są łatwe do zidentyfikowania. Trudno jednak z samej 
architektury systemu TEI wnioskować, że nagle otworzyło się przed nami jakieś zupełnie nowe edytorstwo. Nowe są tylko narzędzia.

Nie wierze $\mathrm{w}$ zmierzch edycji krytycznych, wypieranych przez edycje cyfrowe, także dlatego (ale to akurat najmniej istotny argument), że w międzynarodowym ruchu wydawców cyfrowych model tradycyjny jest traktowany jako pełnoprawny, na równi $z$ edycjami dokumentacyjnymi. Bem wskazał przygotowany przez Institut für Dokumentologie und Editorik dokument, który określa sensowne kryteria ewaluacji edycji cyfrowych ${ }^{17}$. W jednym $z$ punktów tej instrukcji jej autorzy uznają, że właściwie sporządzona recenzja powinna zdawać sprawę m.in. $z$ tego, $w$ jakim modelu teoretycznym (oni nazywają to celami i metodami) została edycja przygotowana: czy jest to edycja dzieła, czy dokumentów. Ale trudno z tej instrukcji wyczytać - chociaż może to tylko mój kłopot - żeby w ewaluacji uprzywilejowane były tylko edycje drugiego typu. To raczej wskazówki, jak właściwie dopasować recenzję do tego, co podlega ocenie, lecz bez przykrajania pod jeden szablon.

Chciałbym mocno podkreślić, że tak jest na razie. Nie wiem, w jaka stronę to się rozwinie. Nie można wykluczyć, że nowe technologie informacyjne rzeczywiście nie tyle nawet odnowią edytorstwo naukowe, ile je zupełnie przeorientują. Gdybym miał jednak zaryzykować jakieś przewidywanie w tej sprawie, sformułowałbym je tak: edytorstwo dzieł literackich, dla którego kluczowe jest krytyczne ustalenie tekstu dzieła, pozostanie pełnoprawną subdyscypliną literaturoznawczą tak długo, jak długo ludzie będą czytać literaturę piękną. Nie sądzę, by było to tylko pobożne życzenie.

\author{
Abstract \\ WOJCIECH KRUSZEWSKI John Paul II Catholic University of Lublin \\ ORCID: 0000-0003-1314-4620
}

THE WORK-A HORIZON OF EDITORIAL ACTIVITIES

The paper polemises with Maria Prussak's and Paweł Bem's theses referring to the methodological assumptions of practising scholarly editing. The author formulates a thesis that a critical edition of a literary work is possible, and his line of reasoning employs the categories of a literary work and authorisation. 